\title{
The Involvement of Cellulase and Laminaranase in the Formation of Pythium Protoplasts
}

\author{
By D. E. EVELEIGH, J. H. SIETSMA AND R. H. HASKINS \\ National Research Council of Canada, Prairie Regional Laboratory, \\ Saskatoon, Saskatchewan, Canada
}

(Accepted for publication 27 November 1967)

SUMMARY

Five inducible streptomycete lytic enzyme complexes were equally capable of producing protoplasts from a Pythium sp. strain PRL 2142, when compared on a quantitative basis. Both cellulase and laminaranase from various microbial sources were required to produce the protoplasts under standard conditions. Protease was not required; lipase shortened the survival time of protoplasts. It was concluded from an analysis of the products of enzymic hydrolyses that Pythium sp. PRL 2I 42 cell wall contained cellulose, $\beta$-D- $(\mathrm{I} \rightarrow 3)$ glucan, and a $\beta$-D- $(\mathrm{I} \rightarrow 3)$ glucan possessing $\mathrm{D}$-glucose units attached by $\beta-(\mathrm{r} \rightarrow 6)$-linkages.:

\section{INTRODUCTION}

Glycosidases, lipases and proteases have all been shown to be involved in the formation of fungal 'protoplasts'. However, little quantitative data is available in published form about these enzymes, especially with regard to the degradation of cell wall of oomycetous genera (Villanueva, I966). The cell walls of these genera are known to possess both cellulose and $\beta$-D- $(\mathrm{I} \rightarrow 3)$ glucans and associated gentibiose components (Aronson, Cooper \& Fuller, 1967; Bartnicki-Garcia \& Lippmann, 1967; Wang \& Bartnicki-Garcia, 1966). Streptomycete enzyme systems capable of producing 'protoplasts' from Pythium sp. PRL 2 I 42 have been described by Sietsma, Eveleigh, Haskins \& Spencer, (1967). A qualitative and quantitative analysis of these lytic enzyme systems is now presented; attention is focused on the cellulase, laminaranase, lipase and protease components. Several components of the cell wall are now identified by enzymic techniques.

\section{METHODS}

The preparation of the streptomycete lytic enzyme complexes used in the production of Pythium 'protoplasts' has been described by Sietsma et al. (1967). Other enzymes, used comparatively, included a Streptomyces sp. B 8I4 cellulase (E.C. 3.2.4.4, from E. T. Reese: Reese \& Mandels, 1963), Aspergillus niger cellulase, subtilisin (E.C. 3.4.4.16; from Nutritional Biochemical Corporation, Cleveland, Ohio), Rhizopus arrhizus laminaranase (E.C. 3.2. 1.6; Reese \& Mandel, 1963), bacterial laminaranase (given by Glaxo Laboratories, England: see Manners \& Patterson, 1966), trypsin (E.C. 3.4.4.4; from Armour Laboratories, Chicago, Illinois), wheat germ lipase (E.C. 3.I.I.3; from Pentex, Kankakee, Illinois), purified pork pancreatic lipase (given by C. G. Youngs, P.R.L., N.R.C., Saskatoon). 
Substrates used. These were as follows: laminaran $(\beta-\mathrm{D}-(\mathrm{I} \rightarrow 3)$-glucan $)$ and nigeran (mixed $\alpha$-D-(I $\rightarrow 3$ ), $\alpha$-D-(I $\rightarrow 4)$-glucan) (Koch-Light Labs., Colnbrook, England); carboxymethylcellulose (CMC-cellulose-courtesy Hercules Trading Corp., Wilminton, Delaware, U.S.A.); pustulan ( $\beta$-D-(I $\rightarrow 6)$-glucan; from Umbilicaria pustulata -given by E. T. Reese). Purified chitan $(\beta-(\mathrm{I} \rightarrow 4)$ linked 2 acetamido-2-deoxy-Dglucan-crustacean shell) and crown gall $(\beta$-(I $\rightarrow 2)$-D-glucan from Agrobacterium tumefaciens IIBV7) were available at this laboratory. Pythium cell-wall preparations were made by boiling the mycelium (7-day culture) in water for Io min. to inactivate autolytic enzymes, and then homogenizing it in a Waring blendor followed by ultrasonic treatment. The wall preparations were washed three times with water. Although only $50 \%$ breakage of the mycelium was achieved, its coenocytic nature allowed complete loss of cytoplasm as judged by random microscopic examination.

The glycosidases of the lytic enzyme preparations were investigated by reacting enzyme solution ( $0 \cdot \mathrm{I})$ with a range of polysaccharides $(3 \mathrm{mg} . / \mathrm{ml}$.; $0 \cdot \mathrm{I} \mathrm{ml}$.) for $\mathrm{I} 6 \mathrm{hr}$ at room temperature. Thiomersalate $0.005 \%$ was used as a bacterial inhibitor. The reactions were terminated by heating at $100^{\circ}$ for $10 \mathrm{~min}$. The degree of hydrolysis and the lytic products were characterized by paper chromatography (solvent c-see below). The enzyme preparations were quantitatively tested for $\beta$-D- $(\mathrm{I} \rightarrow 3)$-glucanase (laminaranase) and cellulase $(\mathrm{Cx})$ by using laminaran and carboxymethylcellulose as substrates respectively. The assays were done with $0.5 \mathrm{ml}$. substrate $(5 \mathrm{mg}$. $/ \mathrm{ml}$. $)+$ enzyme and $0.05 \mathrm{M}$-sodium acetate buffer $\left(\mathrm{pH}_{5} .8\right)$ to $\mathrm{I} \cdot 0 \mathrm{ml}$. at $30^{\circ}$, for 15 (or occasionally 30) min. The reactions were allowed to run to a maximum of $5 \%$ substrate degradation in order to maintain a stoichometric response between the product and the amount of enzyme added (Eveleigh, 1967; Miller, Blum, Glennon \& Burton, 1960). An enzyme unit is defined as that amount of enzyme which released I $\mu$ mole glucose equivalent/min. at $30^{\circ}$. Reducing end-groups (as glucose equivalents) were estimated by the Nelson-Somogyi method (Neish, 1952). Initially cellulase assays were made on CMCcellulose 0.7 degree of substitution (DS); later assays were made on the 0.4 DS CMCcellulose which is four times more reactive than the 0.7 DS substrate. The data for the cellulase assay were presented on the basis of this latter substrate. Lipase was determined titrimetrically (Marchis-Mouren, Sarda \& Desnuelle, 1959). Olive oil was used as a standard and one lipase unit defined as that amount of enzyme which released ro $\mu$-equiv. acid/min. under standard conditions (Marchis-Mouren et al. 1959). Proteolytic activity was determined by using the protein-dye complex azocoll, as substrate (Calbiochem. tech. Bull. 1966); a unit is defined as 0.00I extinction change/min. at $37^{\circ}, \mathrm{pH} 7 \cdot 5$. Proteins were determined by the Folin phenol method (Lowry, Rosenbrough, Farr \& Randall, I95I) with bovine serum albumin as a standard.

Paper chromatographic analysis was done on Whatman filter paper no. I with the following solvent systems: (a) $n$-butanol + ethanol + water ( $3+\mathrm{I}+\mathrm{I}$ by vol.); (b) ethyl acetate + pyridine + water $(10+4+3$ by vol. $) ;(c)$ ethyl acetate + acetic acid (glacial) + water $(9+2+2$ by vol. $) ;(d)$ ethylacetate + formic acid + acetic acid + water (I $8+\mathrm{I}+3+4$ by vol.). Reducing compounds were detected with $p$-anisidine. Partial acid hydrolysis of the cell walls was done in $0.4 \mathrm{~N}-\mathrm{H}_{2} \mathrm{SO}_{4}$ at $100^{\circ}$ for periods of $20 \mathrm{~min}$., $\mathrm{I} \mathrm{hr}$ and $3 \mathrm{hr}$. A more complete hydrolysis was performed in $\mathrm{N}-\mathrm{H}_{2} \mathrm{SO}_{4}$ at $100^{\circ}$ for $20 \mathrm{hr}$. Hydrolysates were neutralized with $\mathrm{BaCO}_{3}$, filtered and concentrated in vacuo at room temperature. 


\section{RESULTS}

The initial survey of enzymes present in the crude lytic streptomycete system was done by chromatographic analysis of enzymic hydrolysates and results are presented in Table I. Endo- $\beta$-D-(I $\rightarrow 3)$-glucanase was shown to be present in each system by the production of $\beta$-(I $\rightarrow 3)$-D-linked-oligosaccharide series as degradation products from laminaran. Exo-laminaranase was also shown to be present in three systems (Table I) by their degradation of a Claviceps sp. PRL 1980 glucan (Perlin \& Taber, 1963) to yield glucose and gentiobiose. The presence of both endo- and exo-laminaranases in the Streptomyces sp. or 43 complex was also demonstrated by an n.m.r. analysis of the glucose and oligosaccharide anomers released initially during enzymic degradation of laminaran (i.e. $\alpha$-glucose and $\beta$-laminaribiose $+\beta$-laminaritriose- - unpublished observations). Cellulase and $\beta$-glucosidase were present in each system, though lower levels of the latter enzyme were present in the $S$. albidoflavus system. The activity of two systems towards pustulan is noteworthy. The $\alpha$-glucosidases present in these systems are probably constitutive, as starch has not been reported from Pythium mycelium, and only glucose and mycelium were used for the induction of the lytic enzymes.

Table I. Glycosidase activity of the streptomycete lytic complexes

\begin{tabular}{|c|c|c|c|c|c|}
\hline Substrate & $\begin{array}{l}\text { Strepto- } \\
\text { myces sp. } \\
\text { OI } 43\end{array}$ & $\begin{array}{c}\text { S. satsu- } \\
\text { maensis } \\
\quad 1399\end{array}$ & $\begin{array}{c}\text { Strepto- } \\
\text { myces } \text { sp. } \\
\quad 1294\end{array}$ & $\begin{array}{c}\text { S. globi- } \\
\text { sporus } \\
\text { B } 2872\end{array}$ & $\begin{array}{l}\text { S. albido- } \\
\text { flavus } \\
\text { A I4 }\end{array}$ \\
\hline Cellobiose & + & ++ & ++ & ++ & + \\
\hline Laminaran & ++ & ++ & ++ & ++ & ++ \\
\hline Cellulose (CMC) & ++ & ++ & ++ & + & + \\
\hline Lichenan & ++ & ++ & ++ & ++ & + \\
\hline $\begin{array}{l}\text { Claviceps sp. } \\
\text { PRL I980 glucan }\end{array}$ & + & ++ & + & $\mathrm{nt}$ & nt \\
\hline Pustulan & 0 & + & 0 & + & 0 \\
\hline Crown gall & 0 & 0 & + & 0 & 0 \\
\hline Chitan & 0 & 0 & 0 & 0 & 0 \\
\hline Maltose & ++ & + & 0 & + & o \\
\hline Starch & ++ & ++ & + & 0 & o \\
\hline Nigeran & 0 & 0 & 0 & 0 & o \\
\hline
\end{tabular}

++ , Strong positive reaction; + , positive reaction; o, negative reaction; nt, not tested.

This initial survey was followed by a more detailed analysis of the laminaranase and cellulase activities of the preparations. Lipase and protease were also determined because Acha, Aguirre, Lopez-Belmonte, Villanueva (1966) and Tabata \& Terui (1963), respectively, reported their involvement in 'protoplast' production. The results are presented in Table 2.

It was previously reported (Sietsma et al. 1967) that Streptomyces sp. oI43 and $S$. globisporus lytic enzymes were capable of producing 'protoplasts' from Pythium species, while those from $S$. satsumaensis caused extensive lysis only. A strong correlation is seen between those results and the results presented in Table 2, i.e. systems producing the greatest lysis possessed generally greater amounts of laminaranase and cellulase. The $S$. satsumaensis system also had a major lipase component. The failure to form protoplasts by this system is probably due to the action of this lipase component, as the addition of wheat germ lipase to the other positive systems causes lysis of proto- 


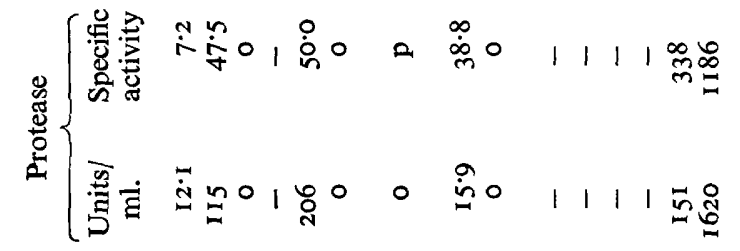

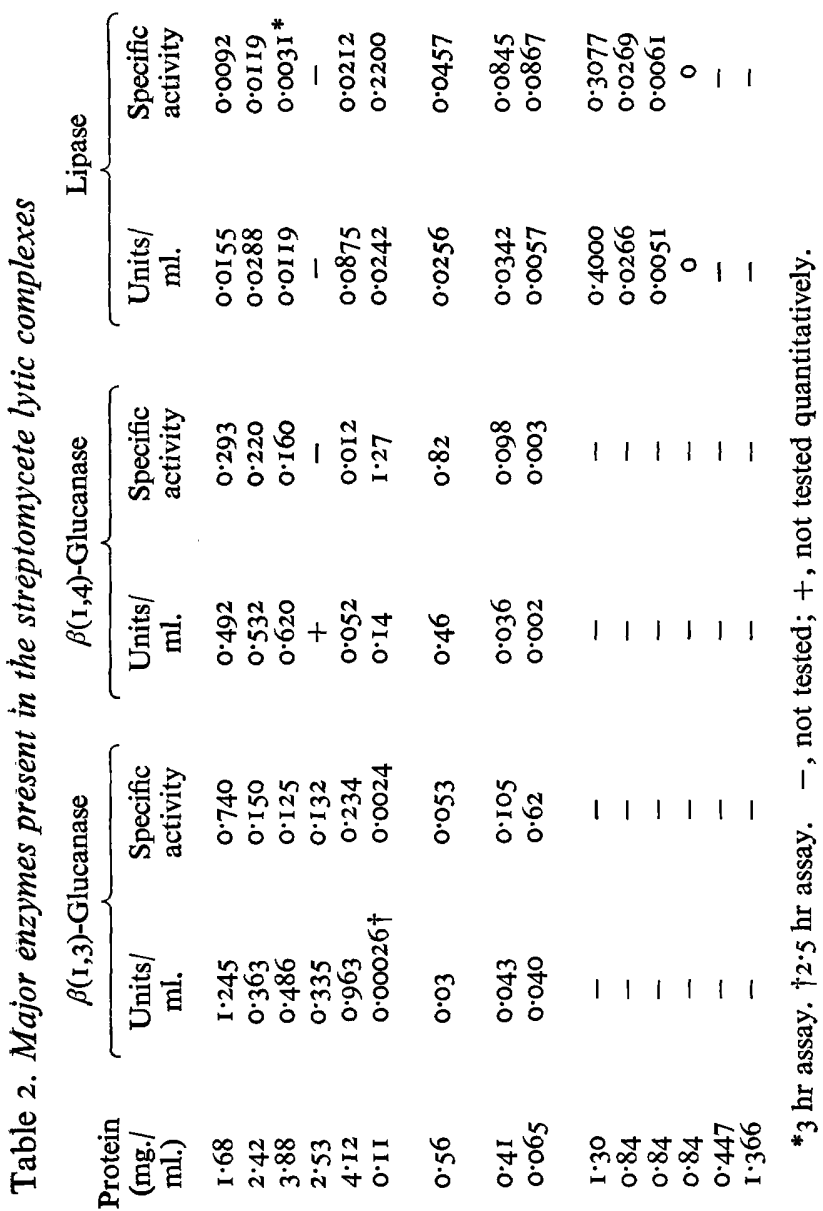

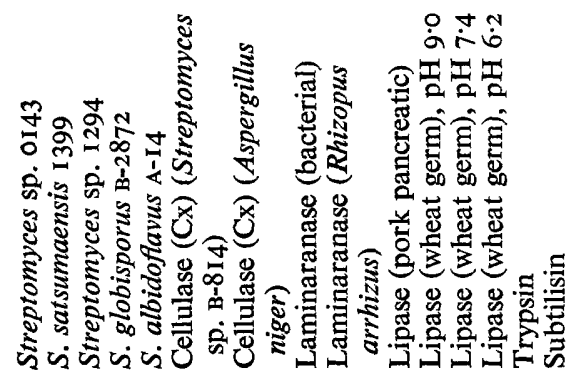


plasts (Sietsma et al. 1967). Two of the systems (S. satsumaensis, S. albidoflavus) possessed marked protease activity. These proteases were assumed to possess limited specificity from a comparison of their reaction kinetics with those of trypsin and subtilisin and other proteases (Calbiochem. tech. Bull. 1966).

The streptomycete lytic enzymes were compared in their ability to produce protoplasts on a quantitative basis with regard to laminaranase activity. The induction of protoplast formation was done as previously described (Sietsma et al. 1967) using $50 \mathrm{mg}$. mycelium (equiv. $5 \mathrm{mg}$. dry wt). The lytic enzymes were added at an equivalent of 0.621 unit laminaranase, i.e. a concentration at which the Streptomyces sp. oI43 preparation $(0.5 \mathrm{ml}$.) showed good protoplast formation. Three streptomycete preparations produced protoplasts after $24 \mathrm{hr}$ incubation at $30^{\circ}$, while that from $S$. satsumaensis caused extensive lysis only (Table 3 ). The $S$. albidoflavus preparation also produced protoplasts, but after continued incubation $(36 \mathrm{hr})$. The slower action of this

Table 3. Comparative amounts of laminaranase and cellulase used for protoplast formation

$\begin{array}{lccc}\text { Laminaranase } & \begin{array}{c}\text { Cellulase } \\ \text { (unit) }\end{array} & \begin{array}{c}\text { Protoplast } \\ \text { produced } \\ \text { after }\end{array} \\ \begin{array}{l}\text { Streptomyces } \text { sp. } 0143 \\ \text { S. satsumaensis }\end{array} & 0.62 \mathrm{I} & 0.246 & 24 \mathrm{hr} \\ \text { Streptomyces } \text { sp. I294 } & 0.62 \mathrm{I} & 0.910 & \begin{array}{c}\text { Complete lysis } \\ \text { in } 24 \mathrm{hr}\end{array} \\ \text { S. globisporus } & 0.62 \mathrm{I} & 0.784 & 24 \mathrm{hr} \\ \text { S. albidoflavus } & 0.62 \mathrm{I} & \mathrm{NT} & 24 \mathrm{hr} \\ & 0.62 \mathrm{I} & 0.032 & 36 \mathrm{hr}\end{array}$

latter preparation was thought to be due to a suboptimal concentration of Cx cellulase. Further trials with various amounts of enzyme (maximum $0.096 \mathrm{Cx}$ units), which included successive dosing with the lytic preparation every $\mathrm{I} 2 \mathrm{hr}$, did not shorten the incubation period of $36 \mathrm{hr}$. Thus the original preparation apparently did not lack sufficient $\mathrm{Cl}$ cellulase and $\mathrm{O} \cdot \mathrm{I}$ unit $\mathrm{Cx}$ cellulase is probably a suboptimal amount of enzyme.

The preparation of Pythium protoplasts was further investigated by using microbial laminaranases and cellulases from various sources. The activities of these preparations are reported in Table 2. Equivalent amounts of the two laminaranases ( 0.75 unit) and of the two cellulases ( 0.5 unit) were added to the standard protoplast-producing incubation system, both singly and together. Samples were examined periodically by phase-contrast microscopy. The results are presented in Table 4. A good correlation is seen between the production of protoplasts and the combined use of laminaranase and cellulase. One exception was found in that the Streptomyces sp. B 8I 4 cellulase, which had a low value of laminaranse, did produce a few protoplasts after $48 \mathrm{hr}$ incubation. The deleterious effect of high concentrations of lipase on protoplast stability was again noticed when bacterial laminaranase or wheat germ lipase was used.

Hydrolysis of Pythium cell walls with dilute sulphuric acid produced glucose (major), laminaribiose and cellobiose, these sugars being identified chromatographically in three solvent systems ( $a, b, c)$. The cell wall was further characterized by enzymic degradation by using the streptomycete lytic preparations. The major products released were glucose, laminaribiose and gentiobiose; cellobiose, laminaritriose, 
laminaritetraose and cellotriose were minor products, with a trace of $4-0-\beta-\mathrm{D}-$ laminaribiosyl-D-glucose. Laminaritriose, laminaritetraose, cellobiose $4-0-\beta$-D-laminaribiosyl-D-glucose and 3-0- $\beta$-D-celliosyl-D-glucose can be separated chromatographically (solvent, $d$, quadruple development). Neither of the latter two compounds were produced in appreciable amounts during time-sequence enzymic cell-wall analysis, whereas the other oligosaccharides did gradually accumulate in spite of the presence of a $\beta$-glucosidase component in the lytic systems. This would indicate that the Pythium sp. PRL 2142 cell walls do not possess a major mixed-linkage $\beta$-D-glucan component of the lichenan type. The cell walls on hydrolysis with a purified basidiomycete exo- $\beta(\mathrm{I} \rightarrow 3)$-D-glucanase (Reese \& Mandels, 1963) yielded both glucose and gentiobiose. Thus a glucan consisting of a $\beta$-D-(I $\rightarrow 3)$-linked main chain with $D$-glucose units attached as branches by $\beta$-D-(I $\rightarrow 6)$-linkages, similar to that obtained from a Claviceps sp., PRL 1980 (Perlin \& Taber, 1963) appeared to be present.

Table 4. Production of Pythium protoplasts by synergistic action of laminaranase and cellulase

\begin{tabular}{|c|c|c|c|c|}
\hline \multirow[b]{2}{*}{ Expt. } & \multirow[b]{2}{*}{ Enzymes } & \multicolumn{2}{|c|}{$\begin{array}{l}\text { Amounts of Enzymes } \\
\text { (units) }\end{array}$} & \multirow{2}{*}{$\begin{array}{l}\text { Protoplast } \\
\text { forma- } \\
\text { tion }\end{array}$} \\
\hline & & Laminaranase & Cellulase & \\
\hline I & Rhizopus arrhizus laminaranase & 0.75 & 0.038 & - \\
\hline 2 & Bacterial laminaranase & 0.75 & 0.628 & $++^{*}$ \\
\hline 3 & Aspergillus niger cellulase & 0.033 & 0.5 & - \\
\hline 4 & Streptomyces sp. B 814 cellulase & 0.0009 & 0.5 & + \\
\hline 5 & $\begin{array}{l}R \text {. arrhizus laminaranase }+A \text {. niger } \\
\text { cellulase }\end{array}$ & 0.783 & 0.538 & ++ \\
\hline 6 & $\begin{array}{l}\text { R. arrhizus laminaranase }+ \text { Strepto- } \\
\text { myces } \text { sp. B } 8 \mathrm{r} 4 \text { cellulase }\end{array}$ & 0.7501 & 0.538 & +++ \\
\hline 7 & $\begin{array}{l}\text { R. arrhizus laminaranase }+ \text { Strepto- } \\
\text { myces sp. B } 814 \text { cellulase }+ \text { wheat germ } \\
\text { germ lipase }(0.5 \mathrm{mg})\end{array}$ & $0.750 \mathrm{I}$ & 0.538 & $+++^{*}$ \\
\hline 8 & $\begin{array}{l}\text { Bacterial laminaranase }+ \text { Strepto- } \\
\text { myces } \text { sp. B 8I4 cellulase }\end{array}$ & 0.7501 & $I \cdot I 28$ & $++^{*}$ \\
\hline
\end{tabular}
$(22 \mathrm{hr}$ ).

* Protoplasts lysed relatively rapidly.

Endo- $\beta$-D-glucanases do not attack this type of glucan. Hence the presence of laminaribiose (major) and cellobiose as products from the action of the streptomycete lytic complexes on Pythium cell walls indicated the presence of an unsubstituted $\beta$-D-(I $\rightarrow 3)$ glucan as the major, and cellulose as a minor, component of these walls. The large amounts of gentiobiose produced in such hydrolyses may have arisen from the $\beta$-D- $(\mathrm{I} \rightarrow 6)$ substituted $\beta$-D- $(\mathrm{I} \rightarrow 3)$ glucan, for the lytic complexes from the Streptomyces sp. strains oI 43, I 294 and 1399 were shown to possess an exo-glucanase by their positive action on the $\beta$-D-(I $\rightarrow 6$ ) substituted Claviceps glucan (Perlin \& Taber, I963). There still remains the possibility that the gentiobiose arose from a $\beta-\mathrm{D}-(\mathrm{I} \rightarrow 6)$ glucan. Pustulanase activity was observed in two of the lytic preparations (Table I). An alkali insoluble glucan fraction has been reported from Phytophthora cinnamomi which contained either separate $\beta$-D- $(\mathrm{I} \rightarrow 3)$ and $\beta$-D- $(\mathrm{I} \rightarrow 6)$ homopolymers or a mixed linkage polymer (Bartnicki-Garia \& Lippman, I967). 


\section{DISCUSSION}

Streptomycete lytic complexes that are capable of lysing the cell walls of the Pythium sp. PRL 2142 have been shown to possess, as major components, exo- and endo-laminaranases and a cellulase. Initially we reported that only two of the five lytic preparations were capable of producing 'protoplasts' (Sietsma et al. 1967). However, when these preparations were compared quantitatively with respect to laminaranase activity four of the preparations produced 'protoplasts', while the other caused complete lysis (Table 3 ). The amounts of enzyme cited allowed the ready formation of protoplasts under our conditions in $24 \mathrm{hr}$. Much smaller amounts of these enzymes plus cellulase will produce some protoplasts. The lowest amount of cellulase (Cx) necessary for protoplast formation appeared to be $0 \cdot I$ unit from the experiments carried out with the Streptomyces albidoflavus complex. The amount of laminaranase generally used $0.621-0.75$ unit (Tables 3,4 ) was probably excessive, since the Streptomyces sp. в 8 I 4 cellulase (0.5 unit) which contained only 0.00093 unit of laminaranase was still capable of forming a few protoplasts in $24 \mathrm{hr}$ (Table 4). Laminaranase 0.00093 unit can release $240 \mu \mathrm{g}$. glucose-equivalent in $24 \mathrm{hr}$ and is quite sufficient, theoretically, to produce protoplasts in this system, especially if the enzyme action was localized. The Pythium sp. PRL 2I 42 possesses a laminaranase (unpublished observation), and the possibility also exists that this enzyme may be activated by the addition of the streptomycete cellulase preparation. An anomaly is seen, however, in that Aspergillus niger cellulase ( 0.5 unit) containing 0.038 unit laminaranase was not capable of producing Pythium protoplasts. Other enzymes may be essential; for instance the presence or even necessity of a Cl cellulase (Mandels \& Reese, 1964) has not been established. Several other factors will also have to be determined (e.g. product inhibition) before the system can be put on a rigorous quantitative basis. At present, a comparison of the amounts of the enzymes used with those of other workers is not informative because of variations in assay procedures and organism studied. A general inference is that in this study smaller amounts of enzyme and longer incubation periods have been used than by other workers (Lloyd, Noveroske \& Lockwood, I965; Mitchell \& Alexander, 1963). Bartnicki-Garcia \& Lippman (1967) used the same Streptomycete sp. B 8I4 cellulase to study the cell walls of Phytophthora cinnamomi and to form protoplasts. The amounts of cellulase they used were higher (about 0.2 unit cellulase/mg. cell wall) than in the present work. A unit of this cellulase (see Methods) approximately equals I0.8 units of Reese \& Mandels (1963). Though the major component of this enzyme preparation is a cellulase, Bartnicki-Garcia \& Lippmann stated that the lytic effectiveness was dependent also on the action of an endo $\beta$-D-(I $\rightarrow 3)$ glucanase.

Lipases have been shown to aid fungal cell-wall degradation (Satamuro, Ono \& Fujomoto, 1960) and in short-term incubation experiments also aid protoplast formation (Acha et al. 1966). It is evident from the results presented with the Pythium sp. PRL 2I42 that the amounts of lipase are critical in protoplast formation; all the preparations tested in this study possessed some lipase activity. Removal of the incubation medium from the protoplasts lengthened their survival time, while addition of more lipase to the incubation medium shortened it. The substrate on which the lipases act at relatively low $\mathrm{pH}$ during protoplast formation is unknown. No wheat-germ lipase activity was detected affer a $3 \mathrm{hr}$ assay at $\mathrm{pH} 6 \cdot 2$ with olive oil as a substrate 
(Table 2). However, the optimum $\mathrm{pH}$ value for lipase action can depend on the substrate and can be relatively low (Wills, I965). One interesting observation is that protoplasts of the Pythium sp. PRL 2142 produced from mycelium grown in the presence of cholesterol are more stable than those obtained from mycelium grown without it. Any relationship between steroids and membrane stability is speculative at present. Proteases have been reported to act synergistically with glycosidases in the degradation of a Sclerotium sp. and yeast cell walls (Satamuro et al. I96o; Tabata \& Terui, 1963). They are, however, not essential for the production of protoplasts from the Pythium sp., since a mixture of lytic preparations from Rhizopus arrhizus and a Streptomyces sp. B 8I4 which lacked protease (Table 2) were effective protoplasts producers (Table 4). It is hoped to purify the components of the Streptomyces lytic enzymes and re-evaluate the protoplast-forming system.

The main components of the Pythium sp. PRL $2 \mathrm{I}_{42}$ cell walls appear to be an unsubstituted $\beta$-D-(I $\rightarrow 3)$-glucan, a $\beta$-D-(I $\rightarrow 6)$ substituted $\beta$ - $\mathrm{D}$ - $(\mathrm{I} \rightarrow 3)$ glucan and cellulose, as judged from the analysis of the products of enzymic hydrolysis. They appear, therefore, to be quite similar to the walls of other oomycetous genera (Aronson et al. 1967; Bartnicki-Garcia \& Lippman, 1967; Wang \& Bartnicki-Garcia, 1966). Mitchell \& Sabar (1966) reported the presence of $\beta$-D-(I $\rightarrow 2)$ glucan in the walls of $P$. butleri, but no evidence for this glucan was found in Pythium sp. PRL 2142. Evidence of layering of cell-wall components has been presented by enzymic techniques (Skujins, Potgieter \& Alexander, I965; Villanueva, 1966). However, no evidence of layering of the Pythium walls has been found from an analysis of 'time-sequence' enzymic hydrolysates.

Several fungi (Lloyd et al. 1965; Potgieter \& Alexander, 1966) show marked resistance to degradation by lytic preparations from other micro-organisms. Lloyd et al. (1965) suggested that fungal lysis in the soil may be an autolytic process, induced by toxic metabolites from antagonistic micro-organisms. The control of Pythium de baryanum in the soil has been achieved by the introduction of micro-organisms capable of lysing its mycelium (Mitchell \& Hurwitz, 1965). The results found with Pythium sp. PRL 2 I 42 indicate that heterolytic mycolysis might be the singular process active in the control of Pythium in the soil.

The authors thank A. Sieben for his competent technical assistance and those cited for gifts of enzymes or substrates. A National Research Council Postdoctorate Fellowship was held by J. H. Sietsma.

\section{REFERENCES}

Acha, I. G., Aguirre, M. J. R., Lopez-Belmonte, F. \& VillanueVa, J. R. (I966). Use of lipase and strepzyme for the isolation of 'protoplasts' from fungal myeclium. Nature, Lond. $209,95$.

Aronson, J. M., Cooper, B. A. \& Fuller, M. S. (1967). Glucans of Oomycete cell walls. Science, N.Y. I55, 332.

BARTNICKI-GARCIA, S. \& LIPPMANN, E. (1967). Enzymic digestion and glucan structure of hyphal walls of Phytophthora cinnamomi. Biochim. biophys. Acta 136, 533 .

Calbiochem. tech. Bulletin. (1966). The use of insoluble protein-dye conjugates for measuring proteolytic activity. Los Angeles, California, U.S.A.

Eveleigh, D. E. (1967). On the determination of $\beta$-I, 3-glucanase-anomalous reduction of alkaline 3,5-dinitrosalicylate. Can. J. Microbiol. 13,727 . 
Lloyd, A. B., Noveroske, R. L. \& Lockwood, J. L. (I965). Lysis of fungal mycelium by Streptomyces spp. and their chitinase systems. Phytopathology 55, $87 \mathrm{I}$.

Lowry, O. H., Rosenbrough, N. J., FarR, A. L. \& Randall, R. J. (I95I). Protein measurements with the Folin phenol reagent. J. biol. Chem. 193, 265.

MANDELS, M. \& REeSE, E. T. (I964). Fungal cellulases and the microbial decomposition of cellulosic fabric. Devs ind. Microbiol. $5,5$.

Manners, D. J. \& Patterson, J. C. (I966). A re-examination of the molecular structure of yeast glucan. Biochem. J. 98, $19 \mathrm{c}$.

Marchis-Mouren, G., Sarda, L. \& Desnuelle, P. (1959). Purification of hog pancreatic lipase. Archs Biochem. Biophys. 83, 309.

MLLLer, G. L., BLUM, R., GlenNon, W. E. \& BURTON, A. L. (I960). Measurement of carboxymethylcellulase activity. Analyt. Biochem. I, 127.

Mitchell, R. \& Alexander, M. (1963). Lysis of soil fungi by bacteria. Can. J. Microbiol. 9, I69.

MrTchell, R. \& HuRwitz, E. (1965). Suppression of Pythium debaryanum by lytic rhizosphere bacteria. Phytopathology 55, 156.

Mrtchell, R. \& Sabar, N. (I966). Hyphal cell wall structure of two species of Pythium. Can. J. Microbiol. 12, 47I.

Neish, A. C. (1952). Analytical Methods for Bacterial Fermentations. Report no. 46.8 .3 (2nd revision). National Research Council, Saskatoon, Saskatchewan.

Perlin, A. S. \& TABer, W. A. (I963). A glucan produced by Claviceps purpurea. Can. J. Chem. 4I, 2278.

Potgleter, H. J. \& Alexander, M. (1966). Susceptibility and resistance of several fungi to microbial lysis. J. Bact. 9I, 1526.

REESE, E. T. \& MANDELS, M. (1963). Enzymatic hydrolysis of $\beta$-glucans. In Advances in Enzymic Hydrolysis of Cellulose and Related Materials. Ed. by E. T. Reese. New York: Pergamon Press.

Satamuro, Y., ONo, M. \& Fuipmoto, J. (I960). Studies on the glucanase of Sclerotinia libertiana. I. Activity of the glucanase on glucans of yeast and sclerotia of the fungus. Bull. agric. chem. Soc. Japan 24, 317.

Sietsma, J. H., Eveleigh, D. E., Haskins, R. H. \& Spencer, J. F. T. (I967). Can. J. Microbiol. I3, I 70 I.

Skujins, J. J., Potgieter, H. J. \& Alexander, M. (i965). Dissolution of fungal cell walls by a Streptomycete chitinase and $\beta$-(I $\rightarrow 3)$ glucanase. Archs Biochem. Biophys. III, 358.

TABAta, S. \& TerU, G. (1963). The microbial enzymes active in hydrolyzing the yeast cell wall. II. Fractionation of the lytic enzyme system. Hakko Kogaku Zasshi 4r, 390. From Chem. Abstr. I $965,63,4585 \mathrm{c}$.

Villanueva, J. R. (1966). Protoplasts of fungi. In The Fungi. Ed. by G. C. Ainsworth and A. S. Sussman. Vol. II, p. 2. New York: Academic Press.

WIILS, E. D. (1965). Lipases. Advanc. Lipid Res. 3, 197.

WANG, M. C. \& BARTNICKI-GARCIA, S. (1966). Biosynthesis of $\beta-1,3$ and $\beta$-I,6-linked glucan by Phytophthora cinnamomi hyphal walls. Biochem. biophys. Res. Comm. 24, 832. 